\title{
Analysis of Calcium (Ca) Levels in Milkfish's (Chanos chanos) Bone Using Atomic Absorption Spectrophotometry (AAS)
}

\author{
*Lia K. Dewi, Supriadi \& Siti Aminah
}

Pendidikan Kimia/FKIP - Universitas Tadulako, Palu - Indonesia 94119

Received 7 December 2020, Revised 11 January 2021, Accepted 5 February 2021

doi: $10.22487 /$ j24775185.2021.v10.i1.pp15-19

\begin{abstract}
Milkfish (Chanos chanos) is famous for Indonesian and has high economic value. Milkfish bone can be processed into flour. A milkfish bone sample was obtained from the Sioyong Market in Dampelas, Donggala. The purpose of this study was to determine the calcium (Ca) levels in milkfish bone using atomic absorption spectrophotometry (AAS). The sample preparation method used dry destruction with sample ignition. The results showed that the average calcium levels in the flesh and head bones of milkfish aged two months were $0.052 \pm$ $0.0007 \%$ and $0.132 \pm 0.0056 \%$, while those at aged five months milkfish were $0.197 \pm 0.0014 \%$ and 0.138 $\pm 00007 \%$, respectively. This study concludes that the older the age of milkfish is, the higher the calcium levels in the bones.
\end{abstract}

Keywords: Milkfish bone (chanos chanos), calcium, atomic absorption spectrophotometry (AAS)

\section{Introduction}

Calcium is the fifth-largest element and the most cation in the human body, which is about 1.5$2 \%$ of the total body weight. Calcium is needed for the process of formation and treatment of skeletal tissues of the body as well as some essential activities in the body such as helping in the regulation of the transport of other ions in and out of the membrane, playing a role in the acceptance and interpretation of nerve impulses, blood clotting, and blood pumping, muscle contraction, maintaining hormonal balance and catalysts in biological reactions (Almatsier, 2002)

Calcium is the most widespread mineral, and approximately there is $1 \mathrm{~kg}$ of calcium in the bones of adults. Bones act as an ionized source of calcium to support nerve function, muscle, and blood clotting. The primary source of calcium in a heavy diet is in small fish eaten with their bones (Miefthawati et al., 2013). Calcium in food is obtained mainly from milk, vegetables, and fish (Almatsier, 2002).

Milkfish (Chanos chanos) is one of the aquaculture fish that the community loves so that it becomes one of the leading aquaculture commodities. Milkfish can live in fresh water and seawater so it is often called brackish water fish (Purnomowati, 2006). Milkfish is a fish resource that has significant economic value. Utilization and market demand of milkfish, increasing from year to year. The highest production occurred in 2018, where milkfish production is 11 million tons
(Direktorat Jenderal Perikanan dan Budidaya, 2013).

According to Trilaksani et al. (2006) fish bones are one form of waste from the fish processing industry that has the most calcium content among fish body parts because the main elements of fish bones are calcium (Ca), phosphorus (P), and carbohydrates $(\mathrm{C})$. In the processing and utilization of fish by households, the parts of fish that are discarded and become waste are the head, tail fins, bones, and innards by producing fish that an average of $65 \%$ has crossed, thus leaving fishery waste by 35\% (Irawan, 1995). This waste, if not handled properly, will cause environmental pollution, especially for human health. Meanwhile, fish bones are a hard component in the body of fish so, decomposition takes a long time.

According to Fitri et al. (2016) there are 82 milkfish bones, not including the head, fins and tail. While Siswanti, et al. (2017) stated that the body parts of fish that are rarely consumed are on fish heads by $18 \%$, fish skin by $4 \%$, fish bones by $8 \%$. Waste milkfish bones can be used as fish bone meal. The nutritional content of fish bone meal contains a lot of calcium, so the benefits of fish bone meal can not be separated from the role of calcium that plays a role in bone formation and maintaining bone loss due to the intake of mineral content is minimal.

In this paper we report on the results of calcium level analysis $(\mathrm{Ca})$ in milkfish bone (Chanos chanos) using atomic absorption spectrophotometry method. 


\section{Methods}

The tools used in this study were Atomic Absorption Spectrophotometry (SSA) GBC 923AA brand, digital balance sheet, measuring gourd, volume pipette, rubber sucker, cathode lamp for calcium, measuring glass, beath glass, steamer cup, stir bar, MMM Medcenter oven, funnel, FB1410M furnace, desiccator, spray bottle and drip pipette.

The materials used in this study were milkfish body bones and head bones (Chanos chanos), concentrated $\mathrm{HNO}_{3}$ (Merck), calcium standard solution (Merck), distilled water, tissue, and filter paper.

\section{Sampling}

The samples used in this study were the body bones and head bones of milkfish (Chanos chanos), which were two months and five months old obtained from the Sioyong market in Dampelas District, Donggala Regency, Central Sulawesi.

\section{Sample Preparation}

Milkfish aged range two and five months separated by body bones with meat, then wash the bones of fish with water until clean, then winded at room temperature. After that clean, the fish head from flesh, skin, gills, and eyes, then wash the bones of the fish head with water until clean, then dried.

\section{Determination of Water Content and Ash Content} Samples of bones and head of milkfish two months and five months have dried, then put in a cup of the steamer and weighed as much as 100 grams, then heated in the oven at a temperature of $110{ }^{\circ} \mathrm{C}$ for \pm 3 hours. After that, it is cooled in a stabilizer and weighed. It then determined the water content with the formula of water content (Sudarmaji et al., 2010).

Samples of body bones and head of milkfish two months are 81.69 grams and 88.69 grams while the bones and head of milkfish five months are 85.06 grams and 87.37 grams of dry that has been obtained and then not in a furnace at a temperature of $800{ }^{\circ} \mathrm{C}$ for \pm 3 hours. Then the ashes obtained are weighed and determined ash levels with the formula of ash content (Sudarmaji et al., 2010).

\section{Sample Setup}

Samples of bone ash and milkfish head two months and five months separated by 10 grams each. Then a concentrated $\mathrm{HNO}_{3}$ solution of 10 $\mathrm{mL}$ is added to each sample, then filtered until separated between filtrates and residues. The acquired filtrate is then diluted with distilled water in a $100 \mathrm{~mL}$ measuring flask to the limit mark.

\section{Calcium Level Analysis}

The milkfish bone samples' solution is taken several $\mathrm{mL}$, and then calcium was analyzed using an atomic absorption spectrophotometer at the wavelength of $422.7 \mathrm{~nm}$.

\section{Results and Discussion}

\section{Water Content and Ash Content in Milkfish Bones}

Water content is one of the parameters that most determine the character and shelf life of a foodstuff. In general, the higher the water content of a foodstuff, the shorter the life of the foodstuff (Winarno, 2004). Water content analysis aims to find out how much moisture content in milkfish bones will be analyzed. There are several methods of water content analysis in the sample, including the drying/oven method, distillation method, and chemical method. In this study, water content analysis using drying method with oven. The process of drying with the oven is based on the principle of calculating the difference in the weight of the sample material before and after drying. The difference in weight is evaporated water and is calculated as the moisture content of the material.

In the measurement of food water content, the measured water is free and adsorbed water. The principle of the drying method is that the water contained in the material will evaporate when the material is heated at $105^{\circ} \mathrm{C}$ during a particular time (Legowo et al., 2007).

The results of this study showed that milkfish body bones and milkfish head bones aged two months each had a water content of $18.31 \%$ and $11.31 \%$, and milkfish body bones and milkfish head bones aged five months each had a water content of $14.94 \%$ and $11.31 \%$. Based on the water content obtained can be said that milkfish bones five months have a shelf life of foodstuffs longer than milkfish bones two months.

Determining a mineral in a foodstuff first carried out the process of destruction or fertilization. This is usually done depending on the nature of organic substances in mineral materials to be analyzed (Arifin, 2008). Analysis of the ash content of a solid sample needs to be determined to perform quantitatively inorganic elements or minerals contained in the sample. Ash content can be analyzed by removing water first dried in the oven at a temperature of $105^{\circ} \mathrm{C}$ (Razak, 2010).

The initial stage of fertilization is a sample of the bones of the body and head of the milkfish two months and five months put in a cup of the steamer that has been known to weigh using a digital balance sheet. The sample is then not used a furnace at a temperature of $800{ }^{\circ} \mathrm{C}$ for \pm 3 hours until it becomes grayish-gray, indicating that the fertilization is perfect. This serves to oxidize all organic substances at high temperatures and speed up and perfect the destructive process. The use of furnaces can also regulate the desired temperature.

The results of this study showed ash levels obtained in the sample of body bones and head bones aged two months, respectively - by $15.19 \%$ and $14.38 \%$, while the body bones and head bones aged five months were $16.51 \%$ and $13.18 \%$, respectively. Based on the ash content obtained, milkfish bones aged five months contain more 
inorganic ingredients than milkfish bones aged two months.

\section{Analysis of Calcium Levels (Ca) in Milkfish Bone Samples}

Determination of calcium levels in samples of body bones and milkfish heads aims to determine the calcium levels in milkfish bones (Chanos chanos) by using the Atomic Absorption Spectrophotometry (SSA) method so that the sample to be measured must be a solution. Therefore, the sample is not for 3 hours to decompose other organic compounds in the sample and facilitate the determination of calcium levels in the sample. Then added nitric acid $\left(\mathrm{HNO}_{3}\right)$ concentrated aims to oxidize organic compounds that are still contained in the sample that has been noted. In addition, other compounds that are still contained in the sample are decomposed so that the inorganic compounds (minerals) are marked by the formation of white ash (Sakka, 2014).

Analysis of calcium concentration in milkfish bone samples using SSA is presented in Tables 1 and 2 .

Table 1. Data on calcium levels in bone samples and milkfish head two months with SSA

\begin{tabular}{rccc}
\hline Sample & Treatment & Sample Concentration $(\mathrm{mg} / \mathrm{L})$ & Calcium Content (\%) \\
\hline \multirow{2}{*}{ Bone Body 2 months } & I & 34.547 & 0.053 \\
& II & 34.355 & 0.052 \\
Average & & $34.451 \pm 0.1357$ & $0.052 \pm 0.0007$ \\
Head bone two months & I & 89.903 & 0.128 \\
& II & 89.518 & 0.136 \\
Average & & $89.710 \pm 0.2722$ & $0.132 \pm 0.0056$ \\
\hline
\end{tabular}

Table 2 Data on calcium levels in samples of body bones and milkfish head five months with SSA

\begin{tabular}{cccc}
\hline Sample & Treatment & Sample Concentration $(\mathrm{mg} / \mathrm{L})$ & Calcium Content $(\%)$ \\
\hline \multirow{2}{*}{ Bone Body 2 months } & I & 120.154 & 0.198 \\
Average & II & 118.998 & 0.196 \\
Head bone two months & & $119.576 \pm 0.8174$ & $0.197 \pm 0.0014$ \\
& I & 105.896 & 0.138 \\
& II & 106.089 & 0.139 \\
\end{tabular}

The results of this study obtained average calcium levels for the body bones and head bones for two months respectively of $0.052 \%$ and $0.132 \%$, while the bones of the body and head bone for five months obtained calcium levels of $0.197 \%$ and $0.138 \%$, respectively. Based on the research can be said that the highest calcium levels are found in the bones of the body and head of milkfish for five months. The difference in calcium levels in milkfish bones two months and five months is caused by age and food. The role of age in the variability of chemical composition is evident in the calcium content of fish bones. The older the fish, the more calcium it tends to be. In addition, the large amount of calcium content of fish is determined by the amount and quality of food provided. The feed provided must be in accordance with the needs of fish (Buwono, 2000).

Calcium levels owned by milkfish bones are relatively lower when compared to other types of fish such as madidihang tuna bones (Thunnus albacares), where the fish bones contain calcium of $13.19 \%$, and in dried fish seawater, there is very high calcium of $756.5 \mathrm{mg} / 100 \mathrm{~g}$ (Afrianti \& Harun, 2011).

Calcium derived from animals such as fish bones until now has not been widely utilized for human needs. Fishbones contain a lot of calcium in the form of calcium phosphate, as much as $14 \%$ (Tiwow et al, 2016) of the whole bone structure.
The complex shape of this phosphate is found in the bones. The main constituents of fish bones are calcium, phosphates, and carbohydrates, while those contained in small amounts are magnesium, sodium, citrate, strontium, fluoride, hydroxide, and sulfate. In the process of bone mineralization, calcium has an essential role because about $80-90 \%$ of bone elements are composed of $\mathrm{Ca}, \mathrm{P}$, and $\mathrm{Mg}$ (Zainuddin, 2010). According to Rocha et al. (2014), calcium and phosphorus are closely related to the development of the skeleton and maintenance and mineralization of bones.

Fitriani et al. (2012) \& Rahmelia et al. (2015) said calcium and phosphorus form calcium phosphate or calcium hydroxyapatite crystals $\left[3 \mathrm{Ca}_{3}\left(\mathrm{PO}_{4}\right)_{2} \mathrm{Ca}(\mathrm{OH})_{2}\right]$ as the main constituents of bone-forming. While according to Ye et al. (2006) $\mathrm{Ca}$ and $\mathrm{P}$ are synergistic minerals and hydroxyapatite in forming bone crystals. Another study conducted by Adebayo et al. (2013) on fish, calcium complex with $\mathrm{P}$ in hydroxyapatite to form the head, tail, bone crystal material and participate in several physiological processes.

The importance of calcium's role for the human body makes milkfish bones (Chanos chanos) as one of the alternative ingredients that can be used as a fishbone meal. According to Trilaksani et al. (2006), a fishbone meal is not very widely used; in other words, a bone meal is a compliment in the manufacture of food. 


\section{Conclusions}

Average calcium levels on the bones of the body and head for two months are $0.052 \pm 0.0007 \%$ and $0.132 \pm 0.0056 \%$. While in the bones of the body and head five months, namely 0.197 $\pm 0.0014 \%$ and $0.138 \pm 0.0007 \%$. The results showed that age affects the calcium levels of milkfish bones.

\section{Acknowledgments}

The author thanks the laboratory of the Regional Health Laboratory of Central Sulawesi Province and all parties who helped the author complete this research.

\section{References}

Afrianti, R., \& Harun, S. (2011). Penentuan kadar kalsium pada ikan kering air laut dan ikan kering air tawar dengan metoda spektrofotometri serapan atom. SCIENTIA: Jurnal Farmasi dan Kesehatan, 1(2), 18-24.

Adebayo, I. A., \& Omitoyin, B. O. (2013). Essentiality of calcium supplement in the diets of Heterobranchus bidorsalis fingerlings. International Journal of Fisheries and Aquaculture, 5(5), 98-103.

Almatsier, S. (2002). Prinsip dasar ilmu gizi. Jakarta: PT. Gramedia Pustaka Utama.

Arifin, Z. (2008). Beberapa unsur mineral esensial mikro dalam sistem biologi dan metode analisisnya. Jurnal Litbang Pertanian, 27(3), 103-104.

Buwono, I. D. (2000) Kebutuhan asam amino esensial dalam ransum ikan. Yogyakarta: Kanisus.

Direktorat Jenderal Perikanan dan Budidaya. (2013). Data statistik series produksi perikanan budidaya Indonesia. Diakses 18 Mei 2019, dari Direktorat Jenderal Perikanan Budidaya Kementerian Kelautan Perikanan Website: http://www.djpb.kkp.go.id/public/upload/stati stik_tahunan/PRODUKSI\%20PB\%202013.p df.

Fitriani, C. N., Walanda, D. K., \& Rahman, N. (2012). Penentuan kadar kalium $(K)$ dan kalsium (Ca) dalam labu siam (Sechium edule) serta pengaruh tempat tumbuhnya. Jurnal Akademika Kimia, 1(4), 174-180.

Fitri., Amiza, R., Baskara, K. A., \& Siswanti. (2016). Penggunaan daging dan tulang ikan bandeng (chanos chanos) pada stik ikan sebagai makanan ringan berkalsium dan berprotein tinggi. Jurnal Teknologi Hasil Pertanian, 9(2), 65-77.

Irawan, A. (1995). Pengolahan hasil perikanan home industri. Solo: CV. Aneka Solo.

Legowo, A. M. (2007). Academic curriculum development buku ajar analisis pangan.
Semarang: Fakultas Dipenegoro Universitas Diponegoro.

Miefthawati, N., Gusrina, L., Axela, F. (2013). Penetapan kadar kalsium pada ikan kembung segar dan ikan kembung asin secara kompleksometri. Jurnal Analis Kesehatan klinikal Sains, 1(1), 1-9.

Purnomowati, I. (2006). Bandeng duri lunak. Yogyakarta: Kanisius.

Razak, R. (2010). Analisis kadar kalsium (Ca) dan magnesium (Mg) pada kacang mete (anacardium occidentale. l) secara spektrofotometri serapan atom. As-Syifaa Jurnal Farmasi, 2(2), 100-104.

Rahmelia, D., Diah, A. W. M., \& Said, I. (2015). Analisis kadar kalium (K) dan kalsium (Ca) dalam kulit dan daging buah terung kopek ungu (solanum melongena) asal desa nupa bomba kecamatan tanantovea kabupaten donggala. Jurnal Akademika Kimia, 4(3), 143148.

Rocha, C. B., Portelinha, M. K., Fernandes, J.M., Britto, A.C.P., Piedras, S. R. M., \& Poue, J. L. O. F. (2014). Dietary phosphorus requirement of pejerrey fingerlings (Odontesthes bonariensis). Revista Brasileira de Zootecni, 43(2), 55-59.

Sakka, L. (2014). Analisis kandungan logam kalsium buah pare (momordica charantia l). dengan menggunakan metode spektrofotometri serapan atom. Jurnal Ilmiah Kesehatan Diagnosis, 3(6), 36-39.

Siswanti, P. Y. A., \& R. Baskara, K. A. (2017). Pemanfaatan daging dan tulang ikan kembung (rastrelliger kanagurta) dalam pembuatan camilan stik. Jurnal Teknologi Hasil Pertanian, 10(1), 41-49.

Sudarmaji, S., Haryono, B., \& Suhardi. (2010). Analisa bahan makanan dan pertanian. Yogyakarta: Liberty Yogyakarta.

Tiwow, V. M., Hafid, I. A., \& Supriadi. (2016). Analisis kadar kalsium (Ca) dan fosforus $(\mathrm{P})$ pada limbah sisik dan sirip ikan mujair (oreochromis mossambicus) dari danau lindu sulawesi tengah. Jurnal Akademika Kimia, 5(4), 159-165.

Trilaksani, W., Salamah, E., \& Nabil, M. (2006). Pemanfaatan limbah tulang ikan tuna (thunnus sp.) sebagai sumber kalsium dengan metode hidrolisis protein. Jurnal Buletin Teknologi Hasil Perikanan, 9(2), 34-43.

Winarno, F. G. (1992). Kimia pangan dan gizi. Jakarta: PT Gramedia Pustaka Utama.

Ye, C. X., Liu, Y. J., Tian, L. X., Mai, K. S., Du, Z. Y., Yang, H. J., \& Niu. J. (2006). Effect of dietary calcium and phosphorus on growth, feed efficiency, mineral content and body composition of juvenil grouper, Epinephelus coioides. Aquaculture, 255(1-4), 263-271. 
Zainuddin. (2010). Pengaruh calsium dan fosfor terhadap pertumbuhan, efisiensi pakan, kandungan mineral dan komposisi tubuh juvenil ikan kerapu macan (epinephelus fuscoguttatus). Jurnal Ilmu dan Teknologi Kelautan Tropis, 2(2), 1-9. 